\title{
Новый «майский указ» Президента: региональные аспекты реализации ${ }^{1}$
}

Т.Г. РАТЬКОВСКАЯ, кандидат экономических наук, Институт экономики и организации промышленного производства СО РАН, Новосибирск. E-mail: rtg@ieie.nsc.ru

Майский указ 2018 г. Президента РФ № 204 стал программным документом, определяющим для всей страны цели и задачи в экономике и социальной сфере на ближайшие шесть лет. Перед субъектами Федерации поставлена задача синхронизировать с этим документом имеющиеся и новые региональные проекты и программы по ключевым направлениям социально-экономического развития. В этой связи автор рассматривает те меры совершенствования межбюджетных отношений в РФ, которые должны способствовать реализации поставленных задач и сглаживанию региональных неравенств. По авторской схеме проведены расчеты и выполнен межрегиональный сравнительный анализ ряда финансовобюджетных показателей в разрезе макрорегионов РФ (федеральных округов). Рассмотрены плюсы и минусы такой новации в межбюджетных отношениях как модельный бюджет региона. На примере муниципальных районов исследована региональная специфика территориальной организации местного самоуправления. Для отдельных субъектов РФ проведен сравнительный анализ структурных характеристик региональных образовательных систем. Сделан вывод о необходимости более полного учета пространственных особенностей социальноэкономического развития регионов в системе межбюджетного выравнивания. Ключевые слова: региональное неравенство; пространственные особенности; межбюджетные отношения; Сибирь

Вопросы регионального развития и неравенства - в том или ином аспекте-непреходящи и актуальны для любой страны мира. В России их характер и решение осложняются как пространственными масштабами государства, так и его федеративным устройством. Соответствующие проблемы рассматриваются в широком спектре научных подходов и разработок ${ }^{2}$.

\footnotetext{
${ }^{1}$ Работа выполнена в рамках государственного задания ФАНО России по проекту XI.173.1.2.(0325-2017-0005) «Стратегическое управление региональным и муниципальным развитием» № AААА-А17-117022250118-6.

${ }^{2}$ Теоретические исследования в области региональной экономики и пространственного развития. Проблемы федерализма и местного самоуправления. Региональная политика. Стратегическое управление пространственным развитием. Институты и механизмы пространственного и регионального развития. Конкретные исследования проблем социально-экономического развития макрорегионов и отдельных регионов России, Сибири и Дальнего Востока и другие.
} 
Данное исследование инициировано принятием Указа Президента РФ № 204 от 7 мая 2018 г. и ставит перед собой следующие задачи:

- выявить и оценить степень межрегионального неравенства с позиций укрупненной оценки обеспеченности финансовыми ресурсами, находящимися в распоряжении региональных и муниципальных органов власти;

- рассмотреть масштабы и остроту существующего межрегионального социально-экономического неравенства в части показателей уровня и условий жизни населения;

- проанализировать характер изменений, вносимых в последнее время в систему межбюджетных отношений, с акцентом на такую новацию, как «модельный бюджет» региона, изначально нацеленную на «справедливое» обеспечение субъектов РФ финансово-бюджетными ресурсами.

\section{Масштаб и значимость указа}

В мае 2018 г. В.В. Путиным было подписано 98 указов, но выражение «новый майский указ» относится к Указу № 204 от 7 мая 2018 г. «О национальных целях и стратегических задачах развития Российской Федерации на период до 2024 года».

Впервые же название «майские указы» закрепилось за серией из 11 указов (№ 596-606), подписанных 7 мая 2012 г. - в день вступления В.В. Путина в должность Президента РФ - и содержащих поручения Правительству РФ для выполнения в течение 2012-2018 гг. В них были прописаны целевые показатели демографической и социальной политики (включая уровни заработной платы в бюджетной сфере), развития в области образования и здравоохранения, обороноспособности страны, роста инвестиционной привлекательности и ряде других направлений.

Рассматривая итоги выполнения тех шестилетней давности поручений и степень достижения целевых показателей, аналитики отмечают, что «реализация майских указов была значительно осложнена падением цен на нефть и санкциями». И хотя в чем-то удалось добиться заметного прогресса (повышение места России в рейтинге Doing Business, увеличение зарплат в образовании и здравоохранении), в других областях прогресса мало (производительность труда, доля инвестиций в экономике, рост реальных зарплат). Так что в некотором смысле новым указом «президент 
идет на вторую попытку» ${ }^{3}$. Серьезной проблемой в этот период стали рекордное увеличение дефицита и рост долговой нагрузки на региональные бюджеты, связанные с необходимостью выполнения майских указов о повышении заработной платы бюджетников.

Новый майский указ издан «в целях осуществления прорывного научно-технологического и социально-экономического развития Российской Федерации, увеличения численности населения страны, повышения уровня жизни граждан, создания комфортных условий для их проживания, а также условий и возможностей для самореализации и раскрытия таланта каждого человека».

В документе перечислены девять национальных целей развития на период до 2024 г. и дано задание Правительству РФ разработать (скорректировать) совместно с органами власти субъектов Российской Федерации национальные проекты (программы) по двенадцати направлениям, а также комплексный план модернизации и расширения магистральной инфраструктуры (на основе Стратегии пространственного развития РФ). Стратегические ориентиры заданы как для показателей уровня и условий жизни населения, так и для экономики страны ${ }^{4}$.

Как отметил премьер-министр Д. Медведев, сам указ в большой степени носит рамочный характер. Все промежуточные цели, тактика - это задачи правительства, которому предстоит разбить весь путь на этапы, установить для каждого из них целевые показатели, контрольные точки и детальные планы, корректируемые по мере необходмости.

Очевидно, что особого внимания потребует финансовая сторона процесса. При этом предстоит учитывать разграничения полномочий между отдельными органами власти и возможности бюджетов различных уровней. «Важно определиться, какие проекты регионы смогут вести сами, где понадобится поддержка из федерального центра, а что федеральному бюджету придется реализовывать самостоятельно» ${ }^{5}$.

\footnotetext{
${ }^{3}$ История повторяется: как исполнялись главные поручения Путина в экономике. URL: https://www.rbc.ru/economics/20/03/2018/5aaf97059a79473279c2effc (дата обращения: 20.08.2018).

${ }^{4}$ Указ «О национальных целях и стратегических задачах развития Российской Федерации на период до 2024 года». URL: http://kremlin.ru/events/president/news/57425 (дата обращения: 29.10.2018).

${ }^{5}$ Времени на раскачку нет //Российская газета. 2018. 21 мая.
} 
Уже 6 июня 2018 г. Правительством РФ утверждены Методические указания по разработке национальных проектов (программ), реализующих положения указа ${ }^{6}$, согласно которым национальные проекты будут состоять из федеральных проектов (с разработанными планами мероприятий на три года - очередной финансовый год и плановый период, с ежегодным уточнением финансового обеспечения). Тем самым намечено обеспечить «скользящее» планирование, синхронизированное с бюджетным циклом. В субъектах РФ создаются региональные проектные офисы, формируются региональные проекты, направленные на реализацию национальных и федеральных проектов и достижение соответствующих целей и показателей.

Со времени своего первого появления (2004-2005 гг.) национальные проекты как инструмент стратегического развития показали свою эффективность ${ }^{7}$. Вместе с тем их роль в развитии соответствующих отраслей социальной сферы не следует абсолютизировать. Основная ответственность и значительный объем расходов по развитию инфраструктуры в регионах приходятся на соответствующие региональные и муниципальные власти и бюджеты, участие которых (в том числе финансовое) в реализации национальных проектов и федеральных целевых программ - необходимое условие. Это стимулирует активность «на местах», однако осложняет участие регионов и муниципалитетов с неблагоприятным состоянием бюджетов и невысокими инвестиционными возможностями.

\section{Финансово-бюджетные ресурсы субъектов Федерации}

Рассмотрим степень и глубину неравенства ряда бюджетных и инвестиционных характеристик на территориях макрорегионов - федеральных округов.

На основе информации о расходах консолидированных бюджетов субъектов РФ нами были рассчитаны удельные показатели

\footnotetext{
${ }^{6}$ Утверждены Методические указания по разработке национальных проектов (программ) для реализации майского указа № 204 [Эл. pecypc]. URL: http:/government. ru/news/32805/ (дата обращения: 20.08.2018).

7 Заседание Совета по реализации приоритетных нацпроектов и демографической политике 26 февраля 2013 года, Московская область, Ново-Огарево. [Эл. ресурс]. URL: http://www.kremlin.ru/events/president/news/17586 (дата обращения: 02.11.2018).
} 
расходов бюджетов на душу населения для каждого из субъектов РФ, агрегированные затем по территориям восьми федеральных округов (табл. 1).

Таблица 1. Структура, объем и уровни расходов консолидированных бюджетов субъектов РФ на территориях федеральных округов РФ на 1 жителя в 2016 г., тыс. руб. (\%)

\begin{tabular}{|c|c|c|c|c|c|c|c|c|}
\hline \multirow{3}{*}{$\begin{array}{c}\text { Федеральный } \\
\text { округ РФ }\end{array}$} & \multirow{3}{*}{ Bcero } & \multirow{3}{*}{$\begin{array}{c}\text { Обще- } \\
\text { госу- } \\
\text { дарст- } \\
\text { венные } \\
\text { вопро- } \\
\text { сы }\end{array}$} & \multirow{3}{*}{$\begin{array}{c}\text { На- } \\
\text { цио- } \\
\text { наль- } \\
\text { ная } \\
\text { эконо- } \\
\text { мика }\end{array}$} & \multirow{3}{*}{$\begin{array}{c}\text { Жи- } \\
\text { лищн- } \\
\text { комму- } \\
\text { нальное } \\
\text { хозяй- } \\
\text { ство }\end{array}$} & \multicolumn{4}{|c|}{$\begin{array}{c}\text { Социально-культурные } \\
\text { мероприятия }\end{array}$} \\
\hline & & & & & \multirow[b]{2}{*}{ всего } & \multicolumn{3}{|c|}{ из них на } \\
\hline & & & & & & $\begin{array}{c}\text { обра- } \\
\text { зова- } \\
\text { ние }\end{array}$ & $\begin{array}{c}\text { здра- } \\
\text { воохра- } \\
\text { нение }\end{array}$ & $\begin{array}{c}\text { соци- } \\
\text { альную } \\
\text { политику }\end{array}$ \\
\hline РФ & $\begin{array}{c}67,7 \\
(100)\end{array}$ & $\begin{array}{c}4,3 \\
(100)\end{array}$ & $\begin{array}{c}13,7 \\
(100)\end{array}$ & $\begin{array}{c}6,4 \\
(100)\end{array}$ & $\begin{array}{r}41,4 \\
(100)\end{array}$ & $\begin{array}{r}17,4 \\
(100)\end{array}$ & $\begin{array}{c}8,7 \\
(100)\end{array}$ & $\begin{array}{r}11,3 \\
(100)\end{array}$ \\
\hline Центральный & $\begin{array}{r}82,9 \\
(122) \\
\end{array}$ & $\begin{array}{c}4,5 \\
(106)\end{array}$ & $\begin{array}{r}19,5 \\
(142)\end{array}$ & $\begin{array}{c}9,7 \\
(152)\end{array}$ & $\begin{array}{c}47,0 \\
(113)\end{array}$ & $\begin{array}{r}17,6 \\
(101)\end{array}$ & $\begin{array}{c}9,3 \\
(107)\end{array}$ & $\begin{array}{r}14,6 \\
(130)\end{array}$ \\
\hline Северо-Западный & $\begin{array}{r}82,5 \\
(122)\end{array}$ & $\begin{array}{c}5,3 \\
(124)\end{array}$ & $\begin{array}{c}18,2 \\
(134)\end{array}$ & $\begin{array}{c}8,0 \\
(125)\end{array}$ & $\begin{array}{c}48,9 \\
(118)\end{array}$ & $\begin{array}{c}20,6 \\
(118)\end{array}$ & $\begin{array}{l}11,1 \\
(127)\end{array}$ & $\begin{array}{c}12,2 \\
(108)\end{array}$ \\
\hline Южный & $\begin{array}{l}47,7 \\
(70)\end{array}$ & $\begin{array}{l}3,3 \\
(78) \\
\end{array}$ & $\begin{array}{l}9,3 \\
(68) \\
\end{array}$ & $\begin{array}{l}2,9 \\
(45) \\
\end{array}$ & $\begin{array}{l}30,5 \\
(73)\end{array}$ & $\begin{array}{l}12,8 \\
(74)\end{array}$ & $\begin{array}{l}6,6 \\
(76)\end{array}$ & $\begin{array}{l}8,4 \\
(74) \\
\end{array}$ \\
\hline Северо-Кавказский & $\begin{array}{l}39,1 \\
(58)\end{array}$ & $\begin{array}{l}2,8 \\
(66)\end{array}$ & $\begin{array}{l}5,6 \\
(41) \\
\end{array}$ & $\begin{array}{l}2,4 \\
(38)\end{array}$ & $\begin{array}{l}27,5 \\
(66)\end{array}$ & $\begin{array}{l}12,2 \\
(70)\end{array}$ & $\begin{array}{l}5,2 \\
(59)\end{array}$ & $\begin{array}{l}8,2 \\
(73)\end{array}$ \\
\hline Приволжский & $\begin{array}{l}50,1 \\
(74)\end{array}$ & $\begin{array}{l}3,2 \\
(76)\end{array}$ & $\begin{array}{l}9,5 \\
(69) \\
\end{array}$ & $\begin{array}{l}3,1 \\
(49)\end{array}$ & $\begin{array}{l}32,5 \\
(78)\end{array}$ & $\begin{array}{l}14,3 \\
(83)\end{array}$ & $\begin{array}{l}6,8 \\
(78)\end{array}$ & $\begin{array}{l}8,4 \\
(74)\end{array}$ \\
\hline Уральский & $\begin{array}{l}81,1 \\
(120)\end{array}$ & $\begin{array}{c}5,1 \\
(121)\end{array}$ & $\begin{array}{r}14,6 \\
(107)\end{array}$ & $\begin{array}{c}7,1 \\
(111)\end{array}$ & $\begin{array}{c}52,2 \\
(126)\end{array}$ & $\begin{array}{c}23,4 \\
(135)\end{array}$ & $\begin{array}{r}11,6 \\
(133)\end{array}$ & $\begin{array}{c}12,4 \\
(110)\end{array}$ \\
\hline Сибирский & $\begin{array}{l}57,6 \\
(85) \\
\end{array}$ & $\begin{array}{l}3,8 \\
(89) \\
\end{array}$ & $\begin{array}{l}8,5 \\
(62) \\
\end{array}$ & $\begin{array}{l}4,1 \\
(64) \\
\end{array}$ & $\begin{array}{l}39,3 \\
(95)\end{array}$ & $\begin{array}{c}17,7 \\
(102)\end{array}$ & $\begin{array}{c}8,8 \\
(101) \\
\end{array}$ & $\begin{array}{l}9,6 \\
(85) \\
\end{array}$ \\
\hline Дальневосточный & $\begin{array}{l}126,1 \\
(186)\end{array}$ & $\begin{array}{c}9,7 \\
(227)\end{array}$ & $\begin{array}{l}25,0 \\
(183)\end{array}$ & $\begin{array}{l}18,7 \\
(293)\end{array}$ & $\begin{array}{c}68,7 \\
(166)\end{array}$ & $\begin{array}{c}30,3 \\
(175)\end{array}$ & $\begin{array}{c}14,1 \\
(161)\end{array}$ & $\begin{array}{c}17,2 \\
(153)\end{array}$ \\
\hline
\end{tabular}

Источник табл. 1, 2, 5, 6: авторские расчеты по данным Росстата.

Для последующего анализа был произведен расчет уровней расходов по каждому из направлений бюджетных расходов (соответствующий показатель по РФ принимался за 100\% и относительно него оценивались аналогичные показатели расходов на территориях всех округов) (табл. 1).

Как показывают данные таблицы, общий уровень расходов консолидированных бюджетов регионов Сибирского федерального округа (СФО) (57,6 тыс.руб.) составил в 2016 г. лишь 85\% от среднего по РФ (67,7 тыс. руб.), а расходов на национальную экономику (8,5 тыс. руб.) - всего $62 \%$ от уровня РФ (13,7 тыс. руб.), это один из самых низких показателей среди всех федеральных 
округов (ниже - только на Северном Кавказе). По разнице между уровнями этих расходов (23 п.п.) СФО - «лидер» в стране. Показатели уровней расходов бюджетов на национальную экономику на территориях Северо-Западного и Центрального ФО даже выше, чем уровень общих расходов (на 20 и 12 п.п. соответственно).

Аналогичные расчеты для 2005-2015 гг. показали, что описанная ситуация типична на протяжении многих лет. Если общий уровень расходов консолидированных бюджетов регионов СФО, благодаря процессам межбюджетного выравнивания, был 83-89\% от среднего по РФ, то уровень расходов на национальную экономику-лишь 64-74\% от среднероссийского показателя с ярко выраженной тенденцией к понижению в последние три года (табл. 2).

Таблица 2. Уровень расходов на национальную экономику консолидированных бюджетов субъектов РФ на территориях федеральных округов в 2010-2016 гг. на 1 жителя, \%

\begin{tabular}{|l|c|c|c|c|c|c|c|}
\hline Федеральный округ & $\mathbf{2 0 1 0}$ & $\mathbf{2 0 1 1}$ & $\mathbf{2 0 1 2}$ & $\mathbf{2 0 1 3}$ & $\mathbf{2 0 1 4}$ & $\mathbf{2 0 1 5}$ & $\mathbf{2 0 1 6}$ \\
\hline РФ & 100 & 100 & 100 & 100 & 100 & 100 & 100 \\
\hline Центральный & 120 & 130 & 127 & 137 & 148 & 137 & 142 \\
\hline Северо-Западный & 120 & 117 & 118 & 117 & 122 & 107 & 134 \\
\hline Южный & 47 & 57 & 71 & 66 & 55 & 61 & 68 \\
\hline Северо-Кавказский & 51 & 51 & 54 & 48 & 44 & 43 & 41 \\
\hline Приволжский & 90 & 79 & 73 & 70 & 71 & 73 & 69 \\
\hline Уральский & 141 & 150 & 149 & 136 & 119 & 117 & 107 \\
\hline Сибирский & 73 & 67 & 71 & 72 & 66 & 66 & 62 \\
\hline Дальневосточный & 177 & 149 & 154 & 168 & 158 & 246 & 183 \\
\hline
\end{tabular}

Следующий этап анализа основывался на предоставляемой Росстатом информации о долевом распределении инвестиций в основной капитал по источникам финансирования. Для каждого субъекта РФ были вычислены соответствующие объемы инвестиций за счет бюджетных средств: всего, и по отдельности из федерального и консолидированного регионального бюджетов. Затем были рассчитаны объемы бюджетных инвестиций на душу населения, их уровень, а также доли расходов на инвестиции в расходах консолидированных бюджетов субъектов РФ на территориях федеральных округов.

В результате расчетов выявлено, что в расходах консолидированных бюджетов регионов СФО и ДФО доли инвестиций были самыми низкими среди федеральных округов на протяжении 
2004-2010 гг. Затем ситуация на Дальнем Востоке улучшилась, чего нельзя сказать о Сибири. В 2016 г. по этому показателю СФО находился на последнем месте (5\%, среднероссийский $-8,2 \%)$.

Сам по себе показатель «доля инвестиций за счет средств консолидированных бюджетов в расходах консолидированных бюджетов», безусловно, важен, но недостаточно информативен. Его необходимо дополнить количественной оценкой объемов и уровня инвестиций, с последующим межрегиональным сопоставлением показателей.

Уровень инвестиций за счет средств консолидированных бюджетов субъектов РФ (на 1 жителя) на территории СФО был особенно (можно сказать «чрезвычайно») низким в 2005-2009 гг.: $48,48,49,53$ и 50\% от среднего значения по РФ. В 2010-2012 гг. наметился рост показателя, однако в 2013-2016 гг. - новое снижение - с 73\% до 52\%. В 2016 г. показатели Сибирского, Южного и Северо-Кавказского округов были самыми низкими - 2,9; 2,8 и 2,2 тыс. руб., соответственно (52, 50 и $41 \%$ от среднего по РФ 5,5 тыс. руб.). Следует отметить, что это те средства, за счет которых, среди прочих направлений, осуществляются расходы на объекты инфраструктуры регионального и местного значения, формируются условия жизни населения на данной территории.

\section{Региональная дифференциация социальных показателей}

О необходимости опережающего, качественно иного развития социальной сферы Востока России говорится не один десяток лет [Сибирь, 2008]. Однако вопрос о том, как обеспечить и поддержать ускоренное социальное развитие Дальнего Востока и Сибири, по-прежнему остается открытым. Заявленный в 2013 г. руководством страны «разворот России на Восток» пока не привел ни к кардинальному увеличению инвестиций в эти территории, ни к улучшению качества жизни населения.

О серьезности положения дел свидетельствуют как показатели сокращения численности населения, так и невысокие характеристики человеческого капитала. По сравнению с 1990 г. количество населения РФ на начало 2017 г. уменьшилось на $0,8 \%$. В восточных округах сокращение было намного существеннее: $8,4 \%$ в Сибирском федеральном округе и $23,7 \%$ - в Дальневосточном. По показателю ожидаемой 
продолжительности жизни оба округа устойчиво занимают последние позиции, хотя отрыв от среднероссийских показателей постепенно уменьшается. К сожалению, того же нельзя сказать о денежных доходах. Если ДФО по этому показателю занимает второе место в РФ, то СФО прочно обосновался на предпоследнем. По доле занятого населения с высшим образованием СФО в 2016 г. находился на последнем месте (табл. 3).

\section{Таблица 3. Характеристики человеческого капитала} в федеральных округах РФ, 2016 г.

\begin{tabular}{|l|c|c|c|c|c|c|c|c|}
\hline \multirow{2}{*}{$\begin{array}{c}\text { Федеральный } \\
\text { округ }\end{array}$} & $\begin{array}{c}\text { Ожидаемая } \\
\text { продолжитель- } \\
\text { ность жизни } \\
\text { при рождении }\end{array}$ & $\begin{array}{c}\text { Среднедуше- } \\
\text { вые денеж- } \\
\text { ные доходы } \\
\text { населения }\end{array}$ & $\begin{array}{c}\text { Доля занятого } \\
\text { населения, име- } \\
\text { ющего высшеe } \\
\text { образование }\end{array}$ & $\begin{array}{c}\text { Число } \\
\text { зарегистриро- } \\
\text { ванных престу- } \\
\text { плений }\end{array}$ \\
\cline { 2 - 11 } & $\begin{array}{c}\text { место } \\
\text { в РФ }\end{array}$ & $\begin{array}{c}\text { в } \\
\text { месяц, } \\
\text { руб. }\end{array}$ & $\begin{array}{c}\text { место } \\
\text { в РФ }\end{array}$ & \% & $\begin{array}{c}\text { место } \\
\text { в РФ }\end{array}$ & $\begin{array}{c}\text { на } \\
\text { 100 тыс. } \\
\text { чел. }\end{array}$ & $\begin{array}{l}\text { место } \\
\text { в РФ }\end{array}$ \\
\hline РФ & 71,07 & & 30744 & & 33,5 & & 1473 & \\
\hline Центральный & 73,07 & 2-е & 39365 & 1-е & 38,7 & 1-е & 1290 & 7-е \\
\hline Северо-Западный & 72,16 & 4-е & 33212 & 3-е & 33,9 & 2-е & 1432 & 4-е \\
\hline Южный & 72,29 & 3-е & 26308 & 5-е & 30,7 & 6-е & 1335 & 6-е \\
\hline Северо-Кавказский & 75,13 & 1-е & 23431 & 8-е & 33,6 & 3-е & 758 & 8-е \\
\hline Приволжский & 71,39 & 5-е & 25737 & 6-е & 30,6 & 7-е & 1367 & 5-е \\
\hline Уральский & 70,82 & 6-е & 32565 & 4-е & 32,2 & 5-е & 1667 & 3-е \\
\hline Сибирский & 69,81 & 7-е & 23720 & 7-е & 29,3 & 8-е & 1978 & 2-е \\
\hline Дальневосточный & 69,22 & 8-е & 36414 & 2-е & 32,5 & 4-е & 1980 & 1-е \\
\hline
\end{tabular}

Источник табл. 3 и 4: данные Росстата.

Начиная с 2004-2005 гг. в стране активно идут процессы модернизации отраслей социальной сферы. По ряду направлений (обеспеченность детей в возрасте 3-7 лет местами в детских садах, развитие акушерской и педиатрических служб и др.) к настоящему времени достигнуты значительные успехи. Однако нерешенных проблем существенно больше. Недовольство населения многих регионов, в том числе в Сибири, вызвало неоправданное закрытие сельских больниц, фельдшерско-акушерских пунктов, «оптимизация» школьной сети. В майском указе 2018 г. озвучена необходимость обеспечения повсеместной доступности первичной медицинской помощи, создания новых и модернизации существующих мест в общеобразовательных учреждениях, ликвидации вторых-третьих школьных смен. 
Рассмотрим для примера проблемы с развитием школьной образовательной сети. По сравнению с 2012 г. ситуация с обеспеченностью местами в общеобразовательных учреждениях РФ (в отличие от дошкольных) изменилась незначительно. При этом положение СФО на фоне других территорий даже ухудшилось (табл. 4): с 6-го места он переместился на 7-е, а по доле школьников, занимающихся во вторую и третью смену, его показатели почти в полтора раза хуже среднероссийского уровня.

Таблица 4. Обеспеченность населения федеральных округов РФ объектами сферы образования в 2012-2017 гг.

\begin{tabular}{|c|c|c|c|c|c|c|c|c|}
\hline \multirow{3}{*}{$\begin{array}{c}\text { Федеральный } \\
\text { округ }\end{array}$} & \multicolumn{4}{|c|}{$\begin{array}{c}\text { Охват детей дошкольными } \\
\text { учреждениями }\end{array}$} & \multicolumn{4}{|c|}{$\begin{array}{c}\text { Удельный вес учащихся } \\
\text { государственных дневных } \\
\text { общеобразовательных учреждений, } \\
\text { занимающихся во вторую смену }\end{array}$} \\
\hline & \multicolumn{2}{|c|}{2012} & \multicolumn{2}{|c|}{2016} & \multicolumn{2}{|c|}{$2012 / 2013$} & \multicolumn{2}{|c|}{$2016 / 2017$} \\
\hline & $\%$ & $\begin{array}{c}\text { место } \\
\text { в РФ }\end{array}$ & $\%$ & $\begin{array}{c}\text { место } \\
\text { в РФ }\end{array}$ & $\%$ & $\begin{array}{l}\text { место } \\
\text { в РФ }\end{array}$ & $\%$ & $\begin{array}{c}\text { место } \\
\text { в РФ }\end{array}$ \\
\hline РФ & 62,1 & & 66,5 & & 14,0 & & 12,8 & \\
\hline Центральный & 65,3 & 5 & 66,5 & 5 & 8,1 & 2 & 6,0 & 2 \\
\hline Северо-Западный & 75,2 & 1 & 76,2 & 1 & 5,3 & 1 & 5,0 & 1 \\
\hline Южный & 56,8 & 7 & 62,3 & 7 & 17,1 & 4 & 15,5 & 4 \\
\hline Северо-Кавказский & 34,4 & 8 & 45,1 & 8 & 24,9 & 8 & 24,3 & 8 \\
\hline Приволжский & 66,6 & 3 & 70,8 & 3 & 11,6 & 3 & 11,3 & 3 \\
\hline Уральский & 70,2 & 2 & 74,1 & 2 & 18,3 & 5 & 17,3 & 6 \\
\hline Сибирский & 57,1 & 6 & 64,2 & 6 & 19,0 & 6 & 18,5 & 7 \\
\hline Дальневосточный & 65,7 & 4 & 68,2 & 4 & 19,4 & 7 & 15,7 & 5 \\
\hline
\end{tabular}

Проблемы социального развития Сибири и Дальнего Востока решать сложнее и дороже, чем в других регионах страны. На протяжении многих десятилетий XX века развитие социальной инфраструктуры региона не успевало за быстрым ростом населения. При дефиците финансовых, материальных и людских ресурсов в условиях отраслевой системы планового управления предпочтение отдавалось непосредственному решению производственных задач. Объекты социальной инфраструктуры создавались по «остаточному» принципу. Молодые города, построенные при металлургических заводах, ЛПК, нефтяных месторождениях и шахтах, были недостаточно приспособлены для развития городской культуры, здорового образа жизни [Перцик, 1980; Тимошенко, 2009]. 


\section{Новации в межбюджетных отношениях}

Таким образом, бюджетные и инвестиционные возможности российских регионов различаются порой кардинально. Почему это происходит? Одним из важных инструментов распределения финансовых ресурсов по территории России является система межбюджетных отношений, включающая в себя налоговое регулирование, распределение полномочий по четырем уровням бюджетной системы РФ, межбюджетные трансферты.

Перспективы развития межбюджетных отношений, стратегия пространственного развития страны, снятие инфраструктурных ограничений были в числе центральных вопросов прошедшего в феврале 2018 г. в Сочи Российского инвестиционного форума ${ }^{8}$.

К числу успехов участники форума отнесли преодоление долговой «ямы» (проведение реструктуризации бюджетных кредитов регионов), выполнение централизации $1 \%$-го налога на прибыль в фонд выравнивания бюджетной обеспеченности, введение в практику модельного бюджета, начало инвентаризации расходных полномочий субъектов Федерации, а также шаги по улучшению прогнозируемости межбюджетных трансфертов (распределение субсидий законом о бюджете на три года вперед).

В числе важнейших задач по развитию межбюджетных отношений в предстоящий период министр финансов РФ А. Силуанов в первую очередь назвал создание условий для развития экономик субъектов РФ, а также финансовое обеспечение полномочий, закрепленных за ними (как за счет собственных доходных источников, так и путем финансовой поддержки из центра через механизм бюджетных трансфертов).

В этой связи предполагается:

- стимулирование регионов к увеличению экономического потенциала (гранты за высокие темпы роста налогового потенциала, возврат прироста налога на прибыль),

- совершенствование принципов и механизмов распределения дотаций на выравнивание бюджетной обеспеченности,

- дальнейшая инвентаризация и регулирование расходных полномочий на всех уровнях бюджетной системы.

\footnotetext{
${ }^{8}$ Встреча с главами регионов в рамках Российского инвестиционного форума «Сочи-2018» [Эл. pecypc]. URL: http:// http://government.ru/news/31397/ (дата обращения: 20.08.2018).
} 
Тема модельного бюджета, введенного в систему межбюджетных отношений в 2017 г., является одной из наиболее актуальных и активно обсуждаемых в региональном сообществе. Его логика состоит в повышении качества механизма выравнивания бюджетной обеспеченности (без чего в нашей «неравновесной» Федерации обойтись невозможно) за счет перехода на другой принцип выравнивания. А именно: при распределении бюджетных средств учитывать не только налоговый потенциал той или иной территории (с последующей корректировкой на индекс бюджетных расходов), но и потребность в финансировании расходных полномочий региональных и местных органов власти на уровне не ниже среднероссийского. Предполагается, что это позволит сфокусировать внимание на реальных обязательствах государства перед гражданами.

Этот принцип впервые был применен Минфином РФ при распределении межбюджетных дотаций на 2017 г. В настоящее время 70\% общего объема дотаций направляется на выравнивание налогового потенциала субъектов РФ (на 1 жителя) с учетом ценовой дифференциации по регионам, а $30 \%$ распределяется с учетом коэффициента, отражающего отношение расчетных расходов на исполнение полномочий региона («модельный бюджет») к фактическим расходам (за прошедший период).

«Модельный бюджет» субъекта определяется следующим образом: по каждой из 23 укрупненных групп полномочий вычисляется объем расчетных расходов на основе сложившегося среднероссийского уровня с учетом факторов, влияющих на стоимость бюджетной услуги. Средний по стране уровень определяется на основе средней величины фактических расходов всех субъектов РФ без учета пяти наивысших и 10 наименьших показателей.

Внедрение модельного бюджета большинством губернаторов было воспринято в целом положительно, но при его использовании был выявлен ряд недостатков, которые должны быть учтены в ходе дальнейшего развития данного механизма. Так, губернатор Архангельской области И. Орлов, выступая на форуме в Сочи, отметил, что в его регионе в число неэффективных расходов попадают малокомплектные школы отдаленных территорий, ряд жизненно необходимых для населения обязательств по здравоохранению. Проблемой является и необходимость субсидирования транспортных затрат для населения региона. 
Губернаторы Сахалинской области (О. Кожемяко), Еврейской AO (А. Левинталь), полпред Президента РФ на Дальнем Востоке Ю. Трутнев в своих выступлениях подчеркивали, что используемые в расчетах методические подходы не в полной мере учитывают реальную ситуацию на Дальнем Востоке: проблемы с транспортной доступностью, большими расстояниями, разреженной и дисперсной инфраструктурой. Председатель Счетной палаты Т. Голикова ${ }^{9}$, отметив падение инвестиций в структуре расходов бюджетов регионов, говорила о необходимости адекватного подхода к отображению инвестиций в модельных бюджетах.

\section{Пространственные особенности условий развития}

Хотя дискуссия о плюсах и минусах нового механизма распределения дотаций еще далека от завершения ${ }^{10}$, можно уже отметить, что его недостатки ярко проявляются в регионах с большой площадью и малой плотностью населения (плотность населения - чаще всего используемый показатель при оценке пространственных особенностей территории). Не менее важны и связанные с ней характеристики территориальной организации местного самоуправления.

При определении границ муниципальных образований в числе основных используется принцип пешеходной и транспортной доступности ${ }^{11}$. Так, границы сельского поселения, как правило, устанавливаются с учетом пешеходной доступности до его административного центра и обратно в течение рабочего дня для жителей всех населенных пунктов, входящих в его состав. Границы муниципального района - с учетом транспортной доступности до его административного центра и обратно в течение рабочего дня. Многие проблемы восточных территорий страны связаны с низкой плотностью населения.

Так, при средней численности населения муниципального района в РФ 30,3 тыс. чел. (на 2017 г.), в СФО этот показатель

${ }^{9}$ Т. И. Голикова занимала эту должность до 16 мая 2018 г. С 22 мая 2018 г. председателем СП РФ является А. Л. Кудрин.

${ }^{10}$ См., например: Что думают главы финорганов о модельном бюджете // Бюджет. 2018. 28 апр. URL: http://bujet.ru/article/343472.php (дата обращения: 20.08.2018).

${ }^{11}$ См. п. 11 ст. 11 Ф3-131 «Об общих принципах организации местного самоуправления в Российской Федерации». 
равен 23 тыс., в ДФО - лишь 19 тыс. (для сравнения: в Южном округе - 48,2 тыс. чел., в Северо-Кавказском - 48,4 тыс. чел.). Если в целом по РФ в небольших муниципальных районах, с численностью до 20 тыс. чел., на начало 2017 г. проживало 7,2\% населения страны, то в СФО - $11,7 \%$. В районах с численностью населения до 30 тыс. чел. показатель по РФ составил 13,3\% (счет идет нарастающим итогом), в СФО - 20,8\%, а в ДФО - 23\%.

Еще более ярко различия видны на уровне отдельных субъектов Федерации. Для анализа нами выбраны субъекты РФ, близкие по численности населения и масштабам экономики, но «контрастные» с точки зрения пространственных условий. Это два субъекта СФО - Алтайский и Забайкальский края и их «антиподы»-Ставропольский край и Астраханская область. Так, Забайкальский край и Астраханская область фактически равны по численности населения (1079,0 и 1018,9 тыс. чел.), а также по долям и численности сельского населения. Однако территория Забайкальского края (431,9 тыс. км²) почти в девять раз превосходит площадь Астраханской области (49 тыс. км²).

В 2016 г. в Алтайском и Забайкальском краях в небольших по численности муниципальных районах (до 20 тыс. чел.) проживало $22,6 \%$ и $18,4 \%$ всего населения (табл. 5). В Ставропольском крае столь мелких районов нет вообще, а в Астраханской области в них проживало лишь 1,9\% населения. В районах с населением до 30 тыс. чел. в Алтайском и Забайкальском краях проживало $34,5 \%$ и $34,2 \%$ всего населения, в то время как в Ставропольском крае и Астраханской области - лишь 3,4\% и 4,4\%.

Таблица 5. Доля населения субъектов РФ, проживающего в муниципальных районах разной величины, в общей численности населения субъекта РФ на 01.01.2017 г., \% нарастающим итогом

\begin{tabular}{|l|c|c|c|c|c|c|c|c|}
\hline \multirow{2}{*}{\multicolumn{1}{c|}{ Регион }} & \multirow{2}{*}{ Всего } & \multicolumn{6}{|c|}{ В том числе с числом жителей, тыс. чел. } \\
\cline { 3 - 9 } & & до $\mathbf{1 0}$ & до15 & до 20 & до $\mathbf{3 0}$ & до 50 & $\begin{array}{c}\text { до } \\
\mathbf{1 0 0}\end{array}$ & $\begin{array}{c}\text { до } \\
\mathbf{1 5 0}\end{array}$ \\
\hline РФ & 38.0 & 1,2 & 3,8 & 7,2 & 13,4 & 21,2 & 30,3 & 34,8 \\
\hline Ставропольский край & 53.8 & - & - & - & 3,4 & 12,7 & 37,3 & 53,8 \\
\hline Астраханская область & 45.1 & - & - & 1,9 & 4,4 & 33,6 & 44,9 & \\
\hline Алтайский край & 45.4 & 3,5 & 13,1 & 22,6 & 34,5 & 40,9 & 45,4 & \\
\hline Забайкальский край & 63.6 & 6,5 & 10,1 & 18,4 & 34,2 & 52,0 & 63,6 & \\
\hline
\end{tabular}


В еще более мелких районах, с населением до 15 тыс. чел., в 2016 г. проживало 3,8\% населения РФ. При этом в Республике Алтай - 39,3\%, Республике Тыва - 37,3\%, Алтайском крае $13,1 \%$, Забайкальском крае - 10,1\%, Томской области $-8,1 \%$. Подобные примеры есть и на территориях других федеральных округов (не говоря о ДФО), но как единичные ситуации. Так, в Орловской области показатель равен 19,2\%, в Псковской $23,4 \%$, Республике Калмыкия - 35,7\%. Однако площадь их территории, система расселения, плотность автодорог, как правило, существенно отличаются от показателей восточных регионов.

Региональные особенности систем расселения (пропорции городского и сельского населения, масштаб и типы населенных пунктов, их топология) и территориальной организации местного самоуправления оказывают непосредственное влияние на характеристики сети объектов социальной инфраструктуры той или иной территории [Региональные проблемы, 1987; Ильин, 2006; Башалханова и др., 2012].

Рассмотрим в выбранных субъектах РФ некоторые характеристики такой отрасли социальной инфраструктуры, как «образование», а именно - 1) государственные общеобразовательные организации (школы) и 2) организации дошкольного образования (табл. 6).

\section{Таблица 6. Некоторые показатели инфраструктуры отрасли} “образование” в субъектах РФ в 2016 г.

\begin{tabular}{|c|c|c|c|c|c|c|}
\hline \multirow[b]{2}{*}{ Регион } & \multicolumn{3}{|c|}{$\begin{array}{c}\text { Общеобразовательные } \\
\text { организации (без вечерних } \\
\text { (сменных))организаций }\end{array}$} & \multicolumn{3}{|c|}{$\begin{array}{c}\text { Организации дошкольного } \\
\text { образования, присмотра } \\
\text { и ухода за детьми }\end{array}$} \\
\hline & $\begin{array}{c}\text { численность } \\
\text { обучаю- } \\
\text { щихся, тыс. } \\
\text { чел. }\end{array}$ & $\begin{array}{c}\text { число } \\
\text { орга- } \\
\text { низа- } \\
\text { ций }\end{array}$ & $\begin{array}{c}\text { “сред- } \\
\text { няя" } \\
\text { числен- } \\
\text { ность }\end{array}$ & $\begin{array}{c}\text { численность } \\
\text { воспитан- } \\
\text { ников, тыс. } \\
\text { чел. }\end{array}$ & $\begin{array}{c}\text { число } \\
\text { орга- } \\
\text { низа- } \\
\text { ций }\end{array}$ & $\begin{array}{c}\text { «сред- } \\
\text { няя" } \\
\text { числен- } \\
\text { ность }\end{array}$ \\
\hline РФ & 14596,3 & 42687 & 342 & 7342,9 & 49370 & 149 \\
\hline Алтайский край & 249,4 & 1038 & 240 & 112,5 & 1264 & 89 \\
\hline Ставропольский край & 267,0 & 622 & 429 & 128,7 & 867 & 148 \\
\hline Забайкальский край & 139,1 & 574 & 242 & 56,3 & 638 & 88 \\
\hline Астраханская область & 108,4 & 285 & 380 & 51,0 & 310 & 165 \\
\hline
\end{tabular}

При близкой численности учащихся сравниваемые субъекты существенно отличаются числом общеобразовательных организаций на своих территориях. Так, в Алтайском крае 
для обучения 249,4 тыс. учеников необходимо (по условиям временно́й и транспортной доступности в системе расселения) почти в два раза больше школ, чем в Ставрополье (1038 против 622 при сопоставимом количестве учащихся). Расчетная «средняя» численность учеников в одной школе в Алтайском крае - 240 чел., в Ставропольском - 429 чел. «Средняя» численность воспитанников в дошкольных организациях Астраханской области - 165 чел., Забайкальского края - 88 чел.

Иными словами, в условиях больших пространств и расстояний, дисперсной системы расселения объективно требуется большее число школ, детских садов, медицинских учреждений, не говоря уже о системе транспортного обеспечения, чем в районах с высокой плотностью населения. Мощности таких объектов, как правило, ниже, а финансовые (в том числе бюджетные) расходы в расчете на одного жителя значительно выше, чем в регионах с иной плотностью населения и компактными системами расселения.

Рассмотренная ситуация отражает одну из причин объективной необходимости более высокой доли текущих затрат на исполнение социальных обязательств муниципальных и региональных органов власти в расходах соответствующих бюджетов на территориях с проблемными экономико-географическими и поселенческими особенностями. В результате в расходах бюджетов вынужденно сокращается инвестиционная составляющая, меньше возможностей для расходов на поддержку национальной экономики. Существующие механизмы государственного управления, выравнивания бюджетной обеспеченности учитывают это обстоятельство недостаточно.

На протяжении ряда лет специалисты говорят о неотложной необходимости институциональной модернизации системы управления социально-экономическим развитием страны с позиций повышения ее адекватности задачам пространственного развития [Крюков и др., 2012; Зубаревич, 2015; Михеева, 2018]. В отсутствие таких изменений многие начинания разрабатываемых стратегий и проектов развития рискуют так и остаться «воздушными замками». 
В ближайшее время достижение целей и исполнение задач нового «майского указа» потребует, среди других решений, дальнейшего совершенствования системы межбюджетных отношений. В числе шагов по этому направлению - необходимость более полного учета пространственных особенностей территории (объективных экономико-географических характеристик, поселенческих условий и других) в системе межбюджетного выравнивания. В противном случае решению задач повышения уровня жизни граждан, создания комфортных условий для их проживания во всех регионах страны, выравнивания пропорций социального развития будут сопутствовать дополнительные трудности.

\section{Литература}

Башалханова Л.Б., Веселова В.Н., Корытный Л. М. Ресурсное измерение социальных условий жизнедеятельности населения Восточной Сибири. Новосибирск: Гео. 2012. $221 \mathrm{c}$.

Зубаревич Н. В. Стратегия пространственного развития после кризиса: от больших проектов к институциональной модернизации // Журнал Новой экономической ассоциации. 2015. № 2 (26). С. 226-230.

Ильин И. А. Социальное строительство на территории России. М.: Наука, 2006. $234 \mathrm{c}$.

Крюков В.А., Кулешов В.В., Селиверстов В.Е. Формирование организационноэкономических механизмов ускорения социально-экономического развития Сибири // Регион: экономика и социология. 2012. № 1. С. 102-122.

Михеева Н.Н. Стратегия пространственного развития: новый этап или повторение старых ошибок? // ЭКО. 2018. № 5. С. 158-178.

Периик Е.Н. Город в Сибири: (проблемы, опыт, поиск решений). М.: Мысль, 1980. $286 \mathrm{c}$.

Региональные проблемы развития социальной инфраструктуры / Под ред. В.П. Можина. М.: Наука, 1987. 272 с.

Сибирь в первые десятилетия ХХІ века / Отв. ред. В. В. Кулешов. Новосибирск: Изд-во ИЭОПП СО РАН, 2008. 788 с.

Тимошенко А. И. Государственная политика формирования и закрепления населения в районах нового промышленного освоения Сибири в 1950-1980-е гг.: планы и реальность. Новосибирск: Сибирское научное издательство, 2009. 174 с.

Статья поступила 10.09.2018.

\section{Summary}

Ratkovskaya T. G., Institute of Economics and Industrial Engineering, SB RAS, Novosibirsk

The New "May Decree" of the President: about the Regional Aspects of the Implementation

The "May decree" (2018) of the President of the Russian Federation No. 204 has become a policy document defining specific goals and objectives in the economy and 
social sphere for the next six years. The constituent entities of the Federation are tasked with synchronizing existing and new regional projects and programs in key areas of socio-economic development with this document. In this regard, the author considers the measures to improve inter-budgetary relations in the Russian Federation, which should contribute to the implementation of the tasks and smoothing regional inequalities. Based on the author's scheme calculations are carried out and the interregional comparative analysis of a number of financial and budgetary indicators in a section of macro-regions of the Russian Federation (Federal districts) is executed. The pros and cons of such innovation in inter-budgetary relations as the model budget of the region are considered. Based on municipal districts the regional specificity of the territorial organization of local self-government is investigated. A comparative analysis of the structural characteristics of regional educational systems within some regions of the Russian Federation was carried. The need to more complete account of the spatial features of the socio-economic development of regions within the system of inter-budgetary relations was expressed.

Regional inequality; spatial features; budget sufficiency; Siberia

\section{References}

Bashalhanova L.B., Veselova V.N., Korytnyj L.M. (2012). Resursnoe izmerenie social'nyh uslovij zhiznedejatel'nosti naselenija Vostochnoj Sibiri. Novosibirsk. Geo Publ. 221 p. (In Russ.).

Zubarevich N.V. (2015). Strategija prostranstvennogo razvitija posle krizisa: ot bol'shih proektov k institucional'noj modernizacii, Zhurnal Novoj jekonomicheskoj associacii [Journal of the New Economic Association]. No. 2 (26). Pp. 226-230. (In Russ.).

Il'in I.A. (2006). Social'noe stroitel'stvo na territorii Rossii. Moscow. Nauka Publ. 234 p. (In Russ.).

Krjukov V.A., Kuleshov V.V., Seliverstov V.E. (2012). Formirovanie organizacionnojekonomicheskih mehanizmov uskoreniya social'no-ekonomicheskogo razvitiya Sibiri. Region: ekonomika I sociologiya [Region: Economics and Sociology]. No. 1. Pp. 102-122. (In Russ.).

Miheeva N.N. (2018). Strategiya prostranstvennogo razvitiya: novyj etap ili povtorenie staryh oshibok? EKO [ECO]. No. 5. Pp. 158-178. (In Russ.).

Percik E. N. (1980). Gorod v Sibiri: (problemy, opyt, poisk reshenij). Moscow. Mysl' Publ. 286 p. (In Russ.).

Regional'nye problemy razvitija social'noj infrastruktury (1987). Moscow. Nauka Publ. 272 p. (In Russ.).

Sibir' v pervye desjatiletija XXI veka (2008). Novosibirsk. IEIE SB RAS Publ. 788 p. (In Russ.).

Timoshenko A.I. (2009). Gosudarstvennaja politika formirovanija i zakreplenija naselenija v rajonah novogo promyshlennogo osvoenija Sibiri v 1950-198-e gg.: plany i real'nost'. Novosibirsk. Sibirskoe nauchnoe Publ. 174 p. (In Russ.). 